\title{
Legemidler som forurensning
}

\author{
Legemidler har gitt nye behandlingsalternativer som har økt livskvaliteten for mange. Sykeligheten har gått \\ ned, og vi lever lenger. Samtidig påvirker all menneskelig aktivitet miljøet vi lever i, og det er viktig å tilpasse \\ vår aktivitet slik at miljøet ikke tar skade. Legemidler i miljøet kan utgjøre et problem, spesielt for organis-
} mer som lever i vann.

\author{
Merete Grung \\ mgr@niva.no \\ Katherine Langford \\ Kevin V. Thomas \\ Norsk institutt for vannforskning (NIVA)
}

I Norge har vi svært god oversikt over forbruket av legemidler, da Nasjonalt folkehelseinstitutt utgir årlige oversikter over legemiddelforbruket, både som en skriftlig rapport og en søkbar Internett-side $(1,2)$. Forbruket av legemidler her i landet har økt de senere årene, og omsetningen utgjorde i 2010 om lag 18 milliarder norske kroner.

I denne kronikken tar vi for oss noen problemområder og beskriver hvordan miljøeffektene kan vurderes. Søkelyset er rettet mot undersøkelser som er gjort i Norge, med hovedvekt på undersøkelser der Norsk institutt for vannforskning (NIVA) har vært involvert.

\section{Risikovurdering av legemidler}

Legemidler ender i miljøet på ulike måter. Etter normal bruk vil selve legemiddelet og/eller metabolittene skilles ut i urin og avføring og havne i avløpsvannet. Midler som kastes i vask/toalett, vil også havne i avløpsvannet. Når de kastes med søppelet, kan legemiddelrester etter hvert sive ut i vann fra avfallsdeponiene. I tillegg forekommer utslipp i forbindelse med produksjon. «Livssyklusen» til legemidler er illustrert i figur 1.

Fordi legemidlene oftest ender i vann, ser man vanligvis etter virkninger av dem her. Når man skal vurdere hvilket avtrykk et legemiddel setter i miljøet, vurderes to størrelser opp mot hverandre. Det ene er hvor mye som slippes ut (miljøkonsentrasjon) og det andre er miljøfaren til legemidlet som slippes ut. Et stort utslipp av et legemiddel som er lite miljøfarlig, vil ikke nødvendigvis skade miljøet. Et lite utslipp av et svært miljøfarlig stoff kan derimot representere et større problem.

Hvor miljøfarlig et legemiddel er, vurderes ut fra stoffets giftighet, hvor lett nedbrytbart det er og stoffets evne til å akku- mulere i fettvev. En nærmere beskrivelse av disse begrepene finnes i kapittel G23 i Norsk legemiddelhåndbok for helsepersonell (3). Mye miljøinformasjon om legemidler finnes også på nettsiden til den svenske bransjeorganisasjonen for legemiddelindustrien (Läkemedelsindustriföreningens Service AB, LIF) (4).

Det er gjennomført relativt få toksisitetstester av legemidler på akvatiske organismer, og derfor er det i mange tilfeller vanskelig å avgjøre hvilken fare de kan utgjøre for miljøet. For alle nye legemidler er det derimot et krav at det gjennomføres en miljørisikovurdering før legemidlet godkjennes, uten at det er satt miljøkrav for godkjenning (5).

På oppdrag fra Klima- og forurensningsdirektoratet (KLIF) utførte NIVA i 2006 og 2007 miljørisikovurderinger av flere legemidler (6). Undersøkelsen viste at fem (ciprofloksacin, diklofenak, etinyløstradiol, paracetamol og tetrasyklin) hadde en teoretisk skadelig konsentrasjon i miljøet $(7,8)$. Et sammendrag av risikovurderingen er gjengitt i Norsk legemiddelhåndbok for helsepersonell 2010 (3). For å gi et riktigere bilde av virkeligheten er det i etterkant av denne første risikovurderingen utført flere målinger av legemidler i miljøet som presenteres i denne kronikken.

\section{Metabolitter kompliserer bildet}

Etter inntak vil de aller fleste legemidler metaboliseres i kroppen. Metabolitter omtales ofte som inaktive, men det betyr ikke at de er uten effekter på akvatiske organismer. Noen kan være mer giftige enn legemiddelet selv. I avløpssystemet tilbakedannes noen metabolitter til det opprinnelige legemidlet pga. dekonjugering. I avløpsvann finnes det derfor en blanding av legemidler og metabolitter. Dette gjør det vanskelig å forutsi og forstå virkningene på organismer som lever i vann. Det er en utfordring å måle konsentrasjonen av alle de ulike legemidlene med sine respektive metabolitter i avløpsvann.

I den første norske studien av legemiddelmetabolitter i avløpsvann, ble forekomsten av metabolitter av atorvastatin, diklofenak, karbamazepin, metoprolol og simvastatin i avløpsvann i Oslo og Tromsø undersøkt (9). For atorvastatin og diklofenak ble metabolittene påvist $\mathrm{i}$ langt høyere konsentrasjon enn morsubstansene. For karbamazepin var konsentrasjonen av den undersøkte metabolitten også høy, men ikke like høy som morsubstansen.

\section{Hvor stort er bidraget fra sykehus?}

Som nevnt er avløpsvann hovedkilden til legemidler og metabolitter i akvatisk miljø. Renseanlegg tar imot avløpsvann fra mange ulike kilder, som husholdninger, kontorer, industri, sykehus og legemiddelprodusenter. Opprinnelig har sykehus hatt størst fokus som en potensiell punktkilde for utslipp av legemidler (10).

Med dette som bakgrunn ble avløpsvann fra Rikshospitalet og Ullevål sykehus undersøkt høsten 2006. Døgnblandprøver fra de to sykehusene ble samlet og analysert for 19 legemidler ukentlig gjennom 12 uker $(11,12)$. Paracetamol og ciprofloksacin var de to legemidlene som gjennomgående ble påvist i høyest konsentrasjoner. Siden sykehus er punktkilder for utslipp av legemidler er det ingen overraskelse at det finnes høye konsentrasjoner i avløpsvannet fra Ullevål og Rikshospitalet. Generelt vil avløpsvannet fra et sykehus reflektere bruken av legemidler ved sykehuset.

I samme tidsrom ble også renseanlegget som renser avløpsvannet fra de to sykehusene analysert for legemidler i innløpet. Undersøkelsen viste at andel legemidler fra sykehusene generelt var svært lav (under $2 \%$ ) mot det som ble målt totalt i renseanlegget (11). Unntaket var paracetamol og trimetoprim, der om lag $12-14 \%$ av legemidlene stammet fra avløpet til de to sykehusene. Brorparten av legemidlene som havner i miljøet stammer derved fra andre kilder, deriblant norske husholdninger.

\section{Hva skjer med legemidler i et renseanlegg}

Renseanleggene i Norge er av svært ulik størrelse og kvalitet. Det aktuelle renseanlegget er et moderne renseanlegg der filtrering, felling, sedimentering og biologisk 


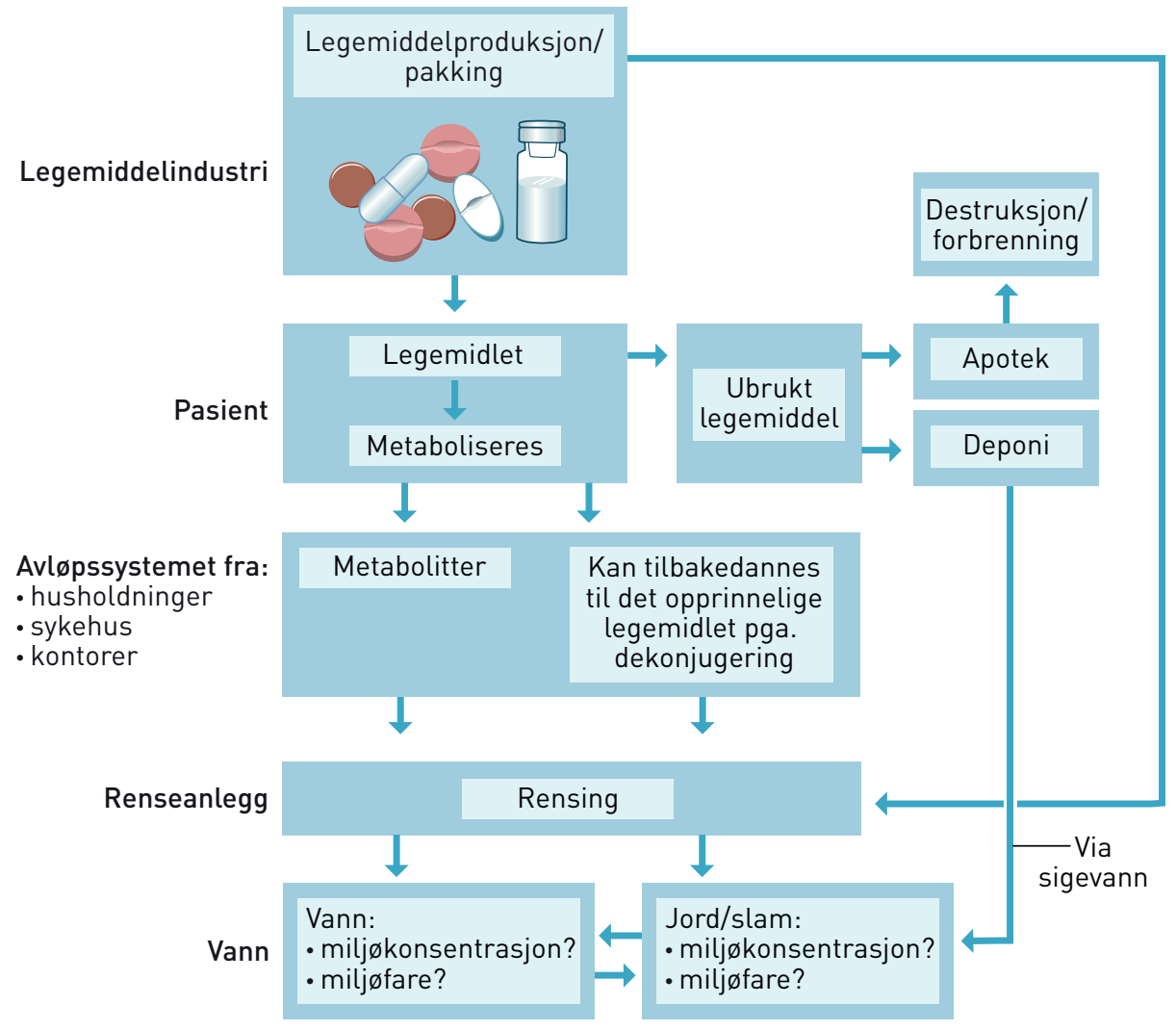

Figur 1 «Livsløpet» til et legemiddel

rensing gjennomføres (14). Slam fra renseanlegget ender opp som jord. Ikke alle norske renseanlegg har like avansert avløpsbehandling, og medikamenter blir fjernet i varierende grad avhengig av hvor moderne anlegget er (7). Ifølge Statistisk sentralbyrå (SSB) er kun halvparten av Norges befolkning tilknyttet et renseanlegg som renser avløpsvannet med høygradige (biologisk/kjemiske) metoder (15).

Avhengig av de fysikalsk-kjemiske egenskapene til legemidlene, vil de enten være vannløselige eller binde seg til partikler. Legemidler som har en affinitet til partikler, vil havne i slammet heller enn i utløpsvannet fra renseanlegg. Konsum av mat som er dyrket i jord tilsatt avløpsslam utgjør ikke noen signifikant helserisiko (16).

I sykehusundersøkelsen beskrevet tidligere $(11,12)$ ble også ukentlige døgnblandprøver av både innløpet og utløpet (renset avløpsvann) samt slam fra renseanlegget undersøkt. Paracetamol var gjennomgående det legemidlet som ble funnet i høyest konsentrasjon. For paracetamol og ibuprofen var rensegraden ofte $99-100 \%$. Andre legemidler, for eksempel metoprolol, diklofenak og trimetoprim, ble ofte målt $i$ høyere konsentrasjoner i utløpet enn i innløpet. En forklaring på dette er at en dekonjugering av metabolitter i renseanlegg er vanlig, slik at morforbindelsen tilbakedannes ved rensing.

\section{Forekomst av legemidler i miljøet - praktisk risikovurdering}

I 2008 ble forekomst av legemidler i sjøvann, marine sedimenter og blåskjell i tillegg til avløpsvann fra sykehus og renseanlegg i Oslo og Tromsø undersøkt på oppdrag fra Klima- og forurensningsdirektoratet (17). Undersøkelsen omfattet 11 legemidler, sju sykehusspesifikke antibiotika, tre røntgenkontrastmidler og fem cytostatika. Basert på analyseresultater og en enkel risikovurdering, ble legemidlene kategorisert etter risiko for effekt på miljøet:

- Liten eller ingen miljømessig bekymring

- amitriptylin, amoksicillin, atorvastatin, bortezomib, cefotaksim, cefalotin, docetaksel, dokorubicin, iodixanol, irinotecan, joheksol, jopromid, meropenem, ofloksacin, paracetamol, paklitaksel, penicillin G, pivmecillinam, sertralin, spiramycin, warfarin

- Noe miljømessig bekymring

- tamoksifen, morfin

- Miljømessig bekymring

- karbamazepin, naproksen, propranolol

\section{Konklusjon og anbefalinger}

Legemidler havner i miljøet ved vanlig bruk, og ender ofte i avløpsvann. Enkelte legemidler kan ha uønskede virkninger på miljøet, og det er derfor viktig å tilpasse bruken slik at skadene blir minst mulige. Vi mener det bør være en målsetting at forekomsten av legemidler i miljøet er så lav at miljøet ikke tar skade.

I Sverige gjøres en miljørisikovurdering i legemiddelkomiteene som anbefaler førstehåndspreparater. Vurderingen blir brukt som annenprioritet etter virkninger på menneskers helse, og komiteene kan dermed gjøre en miljøvurdering dersom virkestoffer ellers har lik virkning. Forskrivere har også mulighet for å gjøre en miljøvurdering mellom ellers like virkestoffer. Vi anbefaler derfor at den enkelte lege gjør seg kjent med miljøstatus for de legemidlene han/hun forskriver på for eksempel den svenske legemiddelindutriforeningens nettside (4). Dersom det finnes miljøvennlige behandlingsalternativer, vil vi anbefale at dette velges. Vi oppfordrer til at miljøvurderinger av legemidler kommer inn i omtalen av legemidler etter modell av for eksempel den svenske nettsiden, og at slike vurderinger blir gjennomgått ved utdanning/videreutdanning av helsepersonell.

Studien er delvis finansiert med støtte fra Norges forskningsråd og Klima- og forurensningsdirektoratet. 


\section{Merete Grung (f. 1964)}

er dr.ing. i bioorganisk kjemi. Hun har arbeidet som forsker hos Norsk institutt for vannforskning (NIVA) siden 2001. Hennes interessefelt er analyse og forekomst av miljøgifter, samt risikovurdering av disse substansene i akvatisk miljø.

Forfatter har fylt ut ICMJE-skjemaet og oppgir ingen interessekonflikter.

\section{Katherine Langford (f. 1974)}

er ph.d. i miljøkjemi, med fokus på forekomst og effekter av miljøgifter gjennom renseanlegg. Hun har arbeidet som forsker hos Norsk Institutt for vannforskning (NIVA) siden 2005. Hennes interessefelt er analyse og forekomst av organiske miljøgifter og nedbrytningsprodukter i akvatisk miljøet.

Forfatter har fylt ut ICMJE-skjemaet og oppgir ingen interessekonflikter.

\section{Kevin V. Thomas (f. 1970)}

er ph.d. innen petroleum og miljøkjemi. Han har arbeidet som forskningsleder for økotoksikologi og risikovurdering hos Norsk institutt for vannforskning (NIVA) siden 2005. Hans interessefelter er identifisering, karakterisering og risikovurdering av nye miljøgifter. Forfatter har fylt ut ICMJE-skjemaet og oppgir ingen interessekonflikter.

\section{Litteratur}

1. Sakshaug S, Strøm H, Berg C et al. Legemiddel forbruket i Norge 2006-2010. Oslo: Nasjonalt folkehelseinstitutt, 2011. www.fhi.no/dokumenter/ 84a70895d8.pdf (5.1.2012).

2. Legemiddelforbruket $\mathrm{i}$ Norge. www.legemiddelforbruk. no (5.1.2012)

3. Grung M, Thomas KV. Miljøpåvirkning av legemidler (G23). I: Fjelstad T, red. Norsk legemiddelhåndbok for helsepersonell, 2010: 1973-82. www.legemiddelhandboka.no (5.1.2012)

4. Läkemedelsindustriföreningens Service AB. LIF. FASS.se - Miljöinformation. www.fass.se/LIF/ miljo/miljoinfo.jsp (5.1.2012).

5. EMA (European Medicines Agency). Guideline on the environmental risk assessment of medicinal products for human use. 2006

www.ema.europa.eu/docs/en GB/

document library/Scientific guideline/2009/10/ WC500003978.pdf (5.1.2012).

6. Grung M, Källqvist T, Thomas KV. Initial assessment of eleven pharmaceuticals using the EMEA guideline in Norway, KLIF report TA 2216-2007. www.klif.no/publikasjoner/2216/ta2216.pdf (5.1.2012).

7. Grung M, Källqvist T, Sakshaug $S$ et al. Environmental assessment of Norwegian priority pharmaceuticals based on the EMEA guideline. Ecotoxicol Environ Saf 2008; 71: 328-40

8. Grung M, Heimstad ES, Moe M et al Human and veterinary pharmaceuticals, narcotics and personal care products in the environment. KLIF report TA 2325-2007 2008. www.klif.no/publikasjoner/ 2325/ta2325.pdf (5.1.2012).

9. Langford K. Thomas KV. Input of selected human pharmaceutical metabolites into the Norwegian aquatic environment. J Environ Monit 2011; 13: $416-21$

10. Thomas KV, Langford K. Point sources of human pharmaceuticals into the aquatic environment. I: Green and sustainable pharmacy. Osnabrück: Springer, 211-23.
11. Thomas KV Dye C, Schlabach M et al. Source to sink tracking of selected human pharmaceuticals from two Oslo city hospitals and a wastewater treatment works. J Environ Monit 2007; 9: 1410-8.

12. Thomas KV, Langford K, Grung M et al. Occurrence of selected pharmaceuticals in wastewater effluents from hospitals (Ullevål and Rikshospitalet) and VEAS wastewater treatment works. KLIF report TA 2246-2008 2007.

www.klif.no/publikasjoner/2246/ta2246.pdf (5.1.2012).

13. Langford KH, Thomas KV. Determination of pharmaceutical compounds in hospital effluents and their contribution to wastewater treatment works. Environ Int 2009; 35: 766-70.

14. Vestfjorden avløpsselskap (VEAS). www.veas.nu (5.1.2012).

15. Statistisk sentralbyrå (SSB). Avløp, kommunalt, hydraulisk kapasitet. www.ssb.no/vis/emner/01/ 04/20/avlhyd/main.html (5.1.2012).

16. Vitenskapskomiteen for mattrygghet (VKM). Risk assessment of contaminants i sewage sludge applied on Norwegian soils 2009 http://vkm.no/dav/2ae7f1b4e3.pdf (5.1.2012).

17. Schlabach M, Dye C, Kaj L et al. Environmental screening of selected organic compounds 2008. Human and hospital-use pharmaceuticals, aquaculture medicines and personal care products.KLIF report TA 2508-2009, 2009 www.klif.no/publikasjoner/2508/ta2508.pdf (5.1.2012).

Mottatt 12.9. 2011, første revisjon innsendt 12.1. 2012, godkjent 15.3. 2012. Medisinsk redaktør Kristin Viste. 